\title{
Linguistic Representation of 100 Days of Pakistan Tehreek - e - Insaaf in Online Pakistani Newspapers: A Critical Discourse Analysis \& Systematic Functional Linguistic Perspective
}

\author{
Saira Asad, Siti Noor Fazelah Binti Mohd Noor, Lutfan Bin Jaes
}

\begin{abstract}
Politics in the world have become mediatized and the language of actors and their party's holders are represented by newspapers by their own ideological factors. The newspaper language has emerged through speech, beliefs and writing practices [20]. To determine the meaning behind the text of Pakistani newspapers, the theory of Critical Discourse Analysis (CDA) by Norman Fairclough (1995) is employed on hard news of 'Dawn' as an independent newspaper and on 'The News' as a mainstream newspaper of Pakistan. The online newspapers are selected for data selection on 100 days performance in 2018 of Pakistan Tehreek - e - Insaaf (PTI) on specified date 29th November 2018 on coverage of 100 days event based on social actors' performance as 'doer', which comprises of two news reports having 5,276 words. Imran Khan's and his party holders' speeches on the party's performance on 100 days completion of government is taken as a unit for analysis, which is represented in both newspapers differently. The social actors' selection is based on a socio-semiotic approach by van Leeuwen (2005). The social actors in the existing study are 'Pakistan Tehreek - e - Insaaf (PTI)' and 'Pakistan Muslim League - Nawaz (PML-N)'. The Systematic Functional Linguistics tool by Michael Alexander Kirkwood Halliday (2014) is applied to media text for determining the role of social actors by process types as an analytical tool, which is based on the revised work of Matthiessen. 'Dawn' has portrayed happening as a hard news while in contrast, 'The News' compared PTI performance with PML-N with suggestions.
\end{abstract}

Keywords: Online newspapers, Critical Discourse Analysis (CDA), Transitivity Analysis, news institutions, media linguistic work

\section{INTRODUCTION}

Critical Discourse Analysis (CDA) is beneficial by providing insights into the language and ideology relationship (Orpin, 2005). In news values, it always provides a framework by allowing for systematic analysis of constructed values that how the events have been constructed, which leads to examine the news values [5]. Language is an important part of the communication process is now considered as the main

Revised Version Manuscript Received on April 19, 2019.

Saira Asad, Ph.D scholar, Faculty of Applied Sciences, Technology and Human Development, Centre of Language Studies, University Tun Hussein Onn Malaysia (UTHM), 86400, Parit Raja, Batu Pahat, Johar, Malaysia.

Dr. Siti Noor Fazelah Binti Mohd Noor, Senior Lecturer, Faculty of Applied Sciences, Technology and Human Development, Centre of Language Studies, University Tun Hussein Onn Malaysia (UTHM), 86400, Parit Raja, Batu Pahat, Johar, Malaysia.

Dr.Lutfan Bin Jaes, Senior Lecturer, Faculty of Social Science, Centre for General Studies and Co-curricular, University Tun Hussein Onn Malaysia (UTHM), 86400, Parit Raja, Batu Pahat, Johar, Malaysia. medium of political communication. As Hasan [15] stated that the dialectical relationship is between the society and individual with semiotics exchanges in which they interact socially of their social positioning. Halliday [14] stated that in the language, culture is construed which is the choice of system and by the use of language, the situation is construed.

The same in the case of political communication that is mediatized nowadays and the way language is taken shape represented the connection to its background story. The political communication field is defined as a platform of sending, receiving, processing and construction of messages, which influence politics [12]. The portrayal of language by media outlets also represents their ideology. As said by Joseph [20] that the people in a powerful position or desiring to achieve power always deploy language to achieve their aims. Especially in the newspaper the representation in textual form of same news in different newspapers differentiates the ideology of newspapers. As quoted by Page [28] that media organizations are 'political actors' who speak up their language by their persuasive actions. In a democratic process, the journalist and political actors' relationship is grounded in the communication process as a necessary element of it [13] Both are dependent on each other for dissemination of information.

In news media, the discourse representation is obvious to be seen as a process of ideology construction of social importance that is represented by semantics and grammar of texts, which are affected by social determinants and effects [11]. To determine the meaning behind the newspaper text of the same news in two different newspapers is taken in an existing study based on 100 days performance of Pakistan Tehreek - e - Insaaf (PTI) as 'doer', which is based on van Leeuwen (2005) social semiotics framework. The online newspapers have been considered in society as a major and easily accessible source of imparting and receiving information [9] and also a well-established news medium [7].

\section{A. Background of Study}

Pakistan's political history since 1947 shows the rule of the military over half of its existence. The other half is also characterized by tussle among political parties, judiciary 
decisions and government dissolution before ending the five year term. From the 2008 general elections, it is the third time in the history of Pakistan that the government has been given charge to new elected government after successful completion of five-year term in 2018 elections. Basically most of the vote bank goes to Pakistan Muslim League (PML-N) and Pakistan People's Party Parliamentarian (PPP) as being the oldest political parties with majority of the devoted voters. The result of the 2018 elections has a great impact and which changed the political scenario of Pakistan and emerged as the largest ruling coalition. Pakistan Tehreek-e-Insaaf (PTI) declared as a successful political party in 2018 election's result by clinching 149 seats in National Assembly out of 342, whereas PML-N got 82 seats. PTI's has been created on goal including to provide credible leadership for restoring Pakistan's political and economic sovereignty based on system of accountability to eradicate corruption [30].

The cases and judgment by Judiciary against former Prime Minister Nawaz Sharif of PML-N on Avenfield case, which went to his arrest with his daughter initially before elections affected his vote bank and PTI had able to clinch at the top leaving far behind other parties. He was charged with official looted money and misuse of his authority. The efforts in form of 'Azadi March' by PTI in 2014 for 124 days against the election rigging of PML-N and later in 2016 'Panama Case' which disclosed the secret properties worth millions of rupees of PML-N leader Nawaz Sharif by International Consortium Investigate Journalist (ICIJ) with others, smoothen the path of PTI to raise the issue against the then Prime Minister. Eventually it led to his arrest and sentence of ten years initially before elections [4]. He was released after few months in jail as Islamabad High Court suspended his ten years jail term but again jailed against corruption case of Al-Azizia Steel Mills of Saudi Arabia for seven years, in which he is found unable to answer his source of income [4].

\section{B. Media in Pakistan}

The social media forums are extensively used in Pakistan by political parties to strengthen their vote bank. Under various governments' media in Pakistan faced restrictions. As far as Constitution of Pakistan is concerned, about Freedom of Expression, Article 19 states that every citizen of the country have a right of freedom of speech and expression subject to reasonable restrictions imposed by the law of country, in the interest of Islam, security, relations and, defense [29].

It is always seen that the government uses a wide variety of methods to intimidate the press, which continues to hinder the abilities of journalists in providing independent commentary [18]. The treatment of media towards parties, candidates, campaigns and, views always portrayed politically biased in Pakistan. If some issues are frequent and others are less projected, one can explore underlying political bias easily [18].

\section{C. 'Dawn' and 'The News'}

The press has always been an important information dissemination medium for political parties. The role of 'Dawn' which is established in 1941 by the founder of
Pakistan, Quaid e Azam Mohammad Ali Jinnah is always a liberal. It is Pakistan's oldest, leading and one of the most widely read English newspaper among elite and being published by one of largest publication company 'Herald Publication'. It is being published in the broadsheet format and famous for the representation of controversial leftist social agenda [23]. Currently, Hameed Haroon is the Chief Executive Officer of Dawn group.

On the other side 'The News' is a mainstream newspaper by having the largest circulation of 140,000 and being published by the largest publication company 'Jang Publications' established in 1991 in broadsheet format. 'The News' has been founded by Mir Khalil ur Rehman and presently his younger son, Mir Shakil ur Rehman, is the owner. 'The News' is catering to the current, national, international events and newsworthy incidents with having a wide readership.

Both have played their role as per their ideologies in political culture formation since their establishment. 'The News' inclination in lawyers movement (2007-2009) toward PML-N and judiciary shown its inclination in 2008, where it also had got paid advertisements with other newspapers to speak freely about then country's ruler General Pervaiz Musharraf in restricted free media environment as compared to previous media culture [2] and 'Dawn' liberal approach in publishing freely stories like 'it's not over till it's over' [3] shows the different approaches and ideologies of two different newspapers in which newspaper published Pakistan's involvement in India, attack by terrorists in 2008 by quoting Nawaz Sharif, which was indeed a very sensitive issue and statement was published freely in newspaper as an interview without any investigation behind the said statement. It was handled as a current statement by former Prime Minister.

\section{RESEARCH OBJECTIVES}

The existing study is focused on the following research questions.

Research Objective 1: To determine the linguistic representation of 'The News' and 'Dawn' on 100 days of PTI in government.

Research Objective 2: To find the hidden meanings of the same news by both newspapers' coverage.

Research Objective 3: To analyze the coverage in both newspapers of 'PTI' and 'PML-N' on their performances in government by textual analysis in the form of frequencies.

\section{LITERATURE REVIEW}

In the researches of the last five years (2015-2019) the internet is linked with the democratization process of news production and distribution [16], which is also observed in the current political scenario of a world in which online medium is extensively being used for dissemination of information. The linguistics' stances and hidden meaning behind the text of

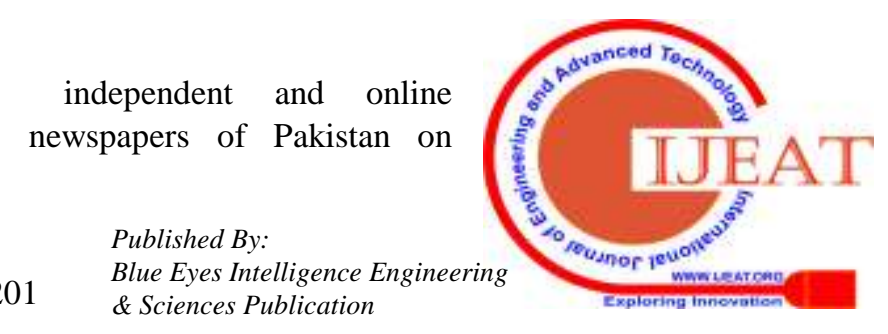


PTI's performance within a standard 100 days, which is a politically worldwide phenomenon to judge the ongoing future framework of government by political parties are not been investigated so far. For filling the gap of independent and mainstream newspapers' linguistics stances, the current study is conducted for bridging this gap and by doing so it will open up new dimensions for future studies to opt the same linguistics analysis framework. As Jóhannsdóttir [19] stated in his study that online traditional newspapers are not shaped by the internet but by their institutional norms. The findings are suggesting that nowadays there is an increase in commercialization in online newspapers and the news has an effect of commercialization, news institutions, and journalists.

Noor [26] studied on online newspapers by having Critical Discourse Analysis and Systematic Functional Linguistics framework. Her work was on the issue of Malaysian graduate employability as construed in public discourse in English. The current study is based on Noor's opted framework where she found direct quotations in mainstream newspapers with the government's representation for showing the supporting material instead of the only the voice of the newspaper. The positive representation was presented of government. In contrast, the independent newspaper had shown liberal textual standing and journalist voice could be heard. On online newspaper research [22] it is stated that the nowadays online newspapers emerge as a source of interactivity. For the need of social interaction, user-user interactivity is driven [22]. By studying the emerging online newspapers in political culture and their different stances on the same news lead to finding out the reason and meanings of different representation. The textual analysis via transitivity leads to find the hidden meaning behind the text along with the news institution's ideology.

\section{METHODOLOGY}

The research is qualitative, where content analysis is the primary method for textual analysis. The textual analysis gives detailed access to the mechanisms by which the social contradictions evolving and are lived out [11]. To analyze the ideology behind the coverage of same news in 'Dawn' as an independent newspaper and 'The News' as mainstream newspaper the theory of Norman Fairclough (1995) Critical Discourse Analysis (CDA) is employed with Michael Alexander Kirkwood Halliday's Systematic Functional Linguistics (SFL) analytical tool for textual analysis. The social actors have been chosen by van Leeuwen's approach (2005) of social semiotics.

\section{A. Critical Discourse Analysis (CDA)}

Critical Discourse Analysis was initially developed by Lancaster School and Norman Fairclough as a researcher was the most prominent figure of it. Dialectical - Relational Approach (DRA) in Critical Discourse Analysis has emerged from 'Critical Linguistics' developed in the 1970s at the University of East Anglia, and these terms are often now interchangeable. It comprises of a number of theories and methodologies. CDA drawing concepts from the social theory and in which valuable contributions are recognized from Karl Marx, Jürgen Habermas, Antonio Gramsci, Louis Althusser,
Michael Foucault and Pierre Bourdieu have to examine ideologies and power relations in discourse. A Dialectical relational approach to CDA creates a link with language, ideology, and power, which shows the relationship between discursive events and social structure [35].

The study employs Foucault's (1980) notion of power. In his concept of power, he gives weight to the human capacity for resisting the force. Struggle for power in Foucault's thoughts includes; struggle against the producing subjects, against the dividing practices and self-subjectivizing [8]. Norman Fairclough's (1995) CDA has been employed as a framework. CDA is considered as a structured functional language theory with social functions and grammar is seen as structured by the three macro language functions i.e. interpersonal, ideational and textual functions [11]. As per Fairclough the first effect on language is by the social cultural practice then it takes the shape of production and interpretation occurs and finally it is represented in the form of written or verbal text. The portrayal of political news' in textual form leaves on influence on readers. As Fairclough [11] stated that texts are spaces of social life by comprising of the process of cognition and social interaction. And by considering language 'context' as a notion leads to a useful investigation [14]. It is creating a dialectical relationship between language and context.

This relationship between different discourses is dialectical, in which language crossing through different phases and a new form emerges. Fairclough [11] stated that CDA is also known as textually orientated theory, which concerns the production and descriptions of text grammatically by viewing language as social semiotic by incorporating the relationship between texts and social structures. In the intertextual analysis, the objective of a text is to describe its 'intertextual configuration', by several text types may be simultaneously combined and drawn upon [11]. Halliday's Systematic Functional Linguistics (SFL) with CDA fully supports Fairclough's statement. Critical Discourse Analysis (CDA) is considered as an analytical technique, which creating awareness concerning the strategies and ways in maintaining, establishing and reproducing relations of power by the means of discourse [36]. In the case of 'The News' and 'Dawn', the difference textual representation of the same news is analyzed via a combination of CDA \& SFL in which grammatically meanings are analyzed to decode the hidden meaning of media representation.

\section{B. Social Semiotic Approach for Social Actor's Selection}

The social actors are used in the analytical discourse category, which is seen as the textual instantiations of models in their specific role. The social actors in the existing study are 'PTI' and 'PML-N' who have been categorized upon their specific role in context. They can be included or excluded, can be in the re-arranged role, can be as a substitution as per

van Leeuwen's

[34] 
International Conference on Recents Advancements in Engineering and Technology (ICRAET-18) |15th and 16th March 2019|Siddhartha Institute of Technology \& Sciences, Telangana, India.

socio-semiotic approach. The social actors from hard news of 'Dawn' and 'The News' have been selected keeping in mind the 'hard news' as 'neutral' and 'facts' reporting, which follows the 'inverted pyramid' in which most important news comes at the top [33].

The news reports are selected based on social actors by employing socio-semiotic framework i.e. Personalization, Individualization, Activation and Passivation, Nomination and Functionalization. In the 'Personalization' role, the rule of influential person is taken for analysis [34]. In 'Individualization' role social actors are chosen as individuals [34]. In the 'Activation' role an actor is identified as a main 'doer' [34], while in 'passivation' role an actor is chosen in the beneficiary role [34]. The selection on 'Nomination' role represents actor with proper noun [34] while in the role of 'Functionalization', social actors are picked up by the functional role in society [34].

\section{Halliday's Systematic Functional Linguistics (SFL)}

Michael Alexander Kirkwood Halliday introduced Systematic Functional Linguistics (SFL) in 1978 initially in the field of linguistics as an analytical tool to differentiate each word within a clause by its lexical and grammatical meaning. SFL has been picked up with CDA in its early stages and can be found in the work of Kress, Hodge, and Trew (1979), van Dijk (1985), Wodak (1989), Fairclough (1989), and Fowler (1996). The authors, who have authored CDA and SFL connection together are Martin (2000) and Young \& Harrison (2004), Halliday \& Matthiessen (2004, 2014), Eggins \& Unworth (2004), van Leeuwen (2005), Halliday \& Greeves (2007) and Martin \& Rose (2007). Their work offers a detailed review of the Halliday theory.

SFL is considered as a functional explanation of text which is lying upon a social- semiotic interpretation of meanings within the context [14]. SFL is emphasized by Thompson [32] that text analysis is one of the main concerns in explanatory relations between the lexico-grammar and its context. SFL focuses on the clausal level by focusing on grammar structure. The analyzation of text occurs in four ways in SFL i.e. context, semantics, lexicogrammar, and phonology. Further categorization in the context of language is in two parts i.e. the context of culture and context of situation. The situation type is further characterized in field, tenor, and mode. The situation emerges in 'Field' [24]. The 'Tenor' describes the language role in socio-semiotic activity [24], while in 'Mode' the role of language in the situation is identified [24].

In context, language has three meta-functions as proposed by Halliday i.e.

a) Interpersonal functions enacting social relations' patterns - tenor.

b) Textual functions presents ideation and interpersonal functions - mode.

c) Ideational functions serving for construing patterns of activity socially - field.

The role of language in 'interpersonal function' describes the relationship between the interaction and semantic organization which grammatically can be found in the structure of 'Mood' clauses [10]. In textual functions, the clause represents as message in the form of 'Theme' and a 'Rheme'[10]. Ideation function describes the language role lexically and grammatically, which comes under lexicogrammar stratum.

\section{Lexicogrammar - Ideation Function}

The existing study has a focus on lexicogrammar stratum under ideation function. As a unit of analysis in larger there is a need to understand the language function. In the ideation function of language, lexicogrammar describes the continuity between the lexis and grammar, which are two different poles of a single continuum which represent as systems of the same features. The analysis of text occurs in ideation function in a clausal form, which comprises of all three metafunctions of language. The clause as the exchange is known as 'Transitivity'. Eggins [10] stated by emphasizing Halliday's SFL rule that the clause semantic representation is analyzed in the following terms:

- Participants ( the roles can be as an actor, goal, sensor, sayer, addressee ,etc.) - nominal group

- Processes (material, verbal, mental, relational, behavioral and existential) - verbal group

- Circumstances (location, manner, etc.) - adverbial group or prepositional phrase

The actor's role is associated with the different process in 'transitivity' by different labels i.e. material, verbal, mental, relational, behavioral and existential. The material clauses bring a change in the event by showing 'action' by a participant - the Actor [24] e.g. 'Hamza' doing his 'work'. In this Hamza is an 'Actor' and his action 'doing' is associated with him. The role of an 'Actor' is associated with other labels in the process are Scope, Client, Recipient, and Attribute. The verbal process creates the dialogic passages as 'Sayer', which describes the role of an actor associated with his spoken words [24] e.g. Shah said that "he will go to the market". In this example 'Shah' as a 'Sayer', who has said about other person (he). The verbal process is categorized into three participant's functions i.e. Receiver, Verbiage, and Target. 'Receiver' who receives the message, 'Verbiage' what has been said and 'Target' relates by having target what to achieve. The mental clause construing a change in the events of our consciousness [24] e.g. I heard a voice. 'Heard' is a mental process, which is perceived mentally. The other roles which are associated with the mental process are 'Sensor' and 'Phenomena'.

The relational clauses act with 'be' and 'have' as the main verb with words of sensing which bring change in a clause [24]. The structure of the relational clause can be either Possessor/Token/Identified or Attribute/Value/Identifier. This process is concerned with possessing, being or becoming, which can either be attributive or identifying e.g. It was an excellent drama which I have ever watched on TV. In this example 'it' is a 'Token', 'an excellent drama' is 'Value' and 'watched on TV' coming under 'Identified'. The behavioral clauses construe change by the participant's behavior [24] e.g. She is eating. In this example 'eating'

shows 'Behavior/Behaving' of an actor. In process of 
existence the 'Theme' is the main feature of the text, which imparts information about its existence [24] e.g. There are many shops of handicrafts. In this example 'there' representing a presence/existence of shops at a particular place.

\section{COLLECTION OF DATA AND ANALYSIS}

On the 100 days' performance of PTI, the main speeches by Imran Khan and his party leaders on 29th November 2018 had taken from online newspapers. They had been represented differently in 'Dawn' as an independent newspaper with 2,066 words and in 'The News' as mainstream newspaper with 3,210 words, which represented two different stances or meanings comprising of 5,276 words combined in the form of two news reports. The sample had taken by keeping in mind the portrayal of 100 days agenda by PTI on 29th November 2018 for which an event was organized especially at Jinnah Convention Centre, Islamabad, Pakistan to highlight the 100 days achievements and promises of the government. The selected news reports were manually downloaded from the internet and pasted in word. For analysis, the data was pasted again in 'Excel' spreadsheet software package in clausal form for textual analysis through the process of 'transitivity'. The text was analyzed for getting to know the relationship of text by looking into the textual meaning. In the analysis, the social actors were selected on van Leeuwen's (2005) approach of socio-semiotics and the rule of 'lexicon' and 'grammar' was followed. Each social actor was analyzed in 'activation and 'passivation' role and under the 'transitivity process'. The social actors' performances were analyzed with the actors' obtained percentages in each process type and role.

\section{RESULTS AND DISCUSSION}

The selection of social actors was based on two categories of van Leeuwen's social semiotics i.e. deletion and role allocation of social actors. The exclusion or inclusion of discourses in elements of the practice can be conducted to represent particular actors who are suitable for one's purpose and interest [34]. Secondly, the reallocation roles of social actors in social relations can be presented. As van Leeuwen [34] stated that the elements of social practices can be rearranged by discourses as in real situations they are in a specific order by applying specific action in that role so there is no change of order required in that context.

'PTI' and 'PML-N' were selected as social actors (doers) to find out the answers of research objectives in the existing study. They were selected through a social semiotic approach of exclusion and rearrangement role in 'activation' and 'passivation'. All news reports were selected where social actors were seen actively participating. The percentage was taken out in the most activated role as 'doer' and benefactor role of the social actor. To determine the role in the transitivity process, each actor's performance was also analyzed against the participant role. It supported the study to verify the results in different roles of the same actor.

Role Allocation of Social Actors

\begin{tabular}{|c|c|c|c|}
\hline \multirow[t]{3}{*}{ Dawn } & Role Allocation & PTI & PML-N \\
\hline & $\begin{array}{l}\text { Activation Total } \\
=77\end{array}$ & $77(100 \%)$ & 0 \\
\hline & $\begin{array}{l}\text { Passivation Total } \\
=3\end{array}$ & $3(100 \%)$ & 0 \\
\hline \multirow{3}{*}{$\begin{array}{l}\text { The } \\
\text { News }\end{array}$} & Role Allocation & & \\
\hline & $\begin{array}{l}\text { Activation Total } \\
=73\end{array}$ & $31(42 \%)$ & $42(58 \%)$ \\
\hline & $\begin{array}{l}\text { Passivation Total } \\
=46\end{array}$ & $27(69 \%)$ & $19(31 \%)$ \\
\hline
\end{tabular}

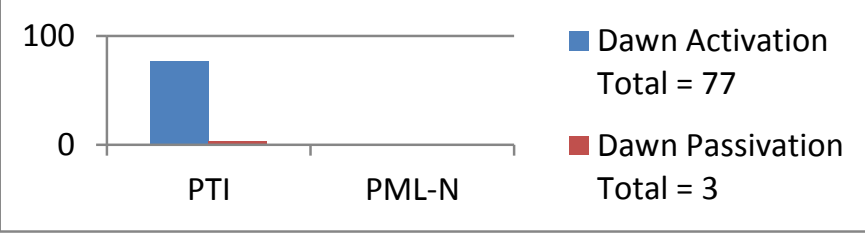

Table 2

Participant Role of Social Actor in 'Dawn'

\begin{tabular}{|l|l|l|}
\hline $\begin{array}{l}\text { Participant } \\
\text { Role }\end{array}$ & PTI & PML-N \\
\hline Actor & $20(25 \%)$ & $\begin{array}{l}\text { No } \\
\text { performance }\end{array}$ \\
\hline Verbiage & $40(50 \%)$ & $\begin{array}{l}\text { No } \\
\text { performance }\end{array}$ \\
\hline Sayer & $12(15 \%)$ & $\begin{array}{l}\text { No } \\
\text { performance }\end{array}$ \\
\hline Token & $1(1 \%)$ & $\begin{array}{l}\text { No } \\
\text { performance }\end{array}$ \\
\hline Scope & $1(1 \%)$ & $\begin{array}{l}\text { No } \\
\text { performance }\end{array}$ \\
\hline Goal & $1(1 \%)$ & $\begin{array}{l}\text { No } \\
\text { performance }\end{array}$ \\
\hline Behavior & $2(3 \%)$ & $\begin{array}{l}\text { No } \\
\text { performance }\end{array}$ \\
\hline Phenomena & $1(1 \%)$ & $\begin{array}{l}\text { No } \\
\text { performance }\end{array}$ \\
\hline Possessor & $2(3 \%)$ & $\begin{array}{l}\text { No } \\
\text { performance }\end{array}$ \\
\hline
\end{tabular}

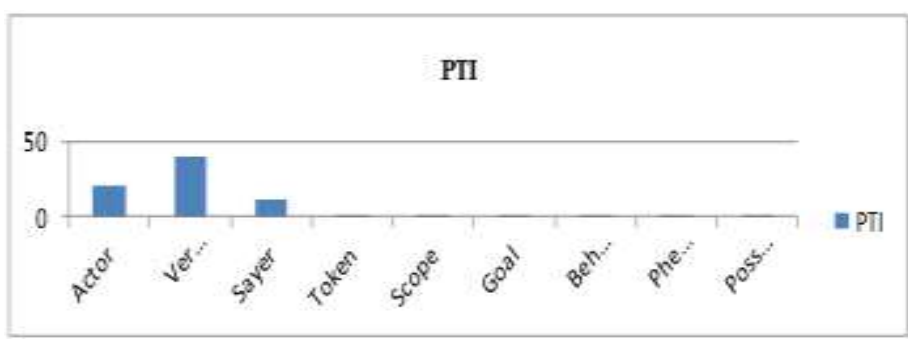

Table 3 
International Conference on Recents Advancements in Engineering and Technology (ICRAET-18) |15th and 16th March 2019|Siddhartha Institute of Technology \& Sciences, Telangana, India.

Transitivity Results of Social Actors in 'Dawn'

\begin{tabular}{|l|l|l|}
\hline Process & PTI & PML-N \\
\hline Material & $22(27 \%)$ & 0 \\
\hline Mental & 0 & 0 \\
\hline Verbal & $52(65 \%)$ & 0 \\
\hline Relational & $4(5 \%)$ & 0 \\
\hline Behavioral & $2(3 \%)$ & 0 \\
\hline
\end{tabular}

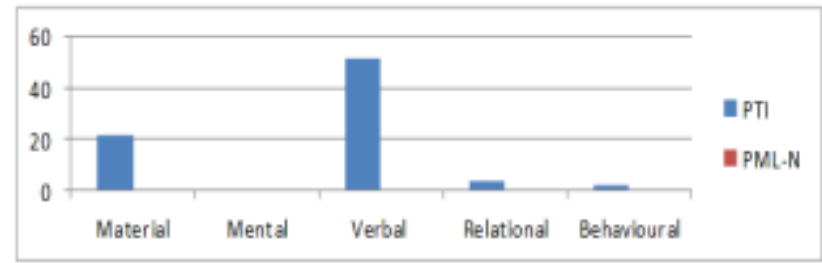

Table 4

Participant Role of Social Actor in 'The News'

\begin{tabular}{|l|l|l|}
\hline $\begin{array}{l}\text { Participant } \\
\text { Role }\end{array}$ & PTI & PML-N \\
\hline Actor & $15(26 \%)$ & $19(31 \%)$ \\
\hline Phenomena & $6(11 \%)$ & $4(6 \%)$ \\
\hline Identified & $4(7 \%)$ & $7(11 \%)$ \\
\hline Possessor & 0 & $1(2 \%)$ \\
\hline Affected & $13(23 \%)$ & $3(5 \%)$ \\
\hline Scope & $2(3 \%)$ & $1(2 \%)$ \\
\hline Token & $2(3 \%)$ & $3(5 \%)$ \\
\hline Sayer & $13(23 \%)$ & $15(25 \%)$ \\
\hline Verbiage & $2(4 \%)$ & 0 \\
\hline Goal & 0 & $2(3 \%)$ \\
\hline Beneficiary & 0 & $5(8 \%)$ \\
\hline Target & 0 & $1(2 \%)$ \\
\hline
\end{tabular}

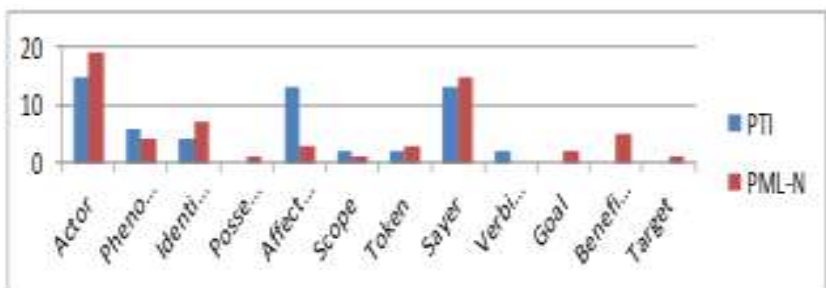

Table 5

Transitivity Results of Social Actors in 'The News'

\begin{tabular}{|l|l|l|}
\hline Process & PTI & PML-N \\
\hline Material & $31(55 \%)$ & $28(46 \%)$ \\
\hline Mental & $5(9 \%)$ & $2(3 \%)$ \\
\hline Verbal & $14(25 \%)$ & $18(30 \%)$ \\
\hline Relational & $6(11 \%)$ & $13(21 \%)$ \\
\hline
\end{tabular}

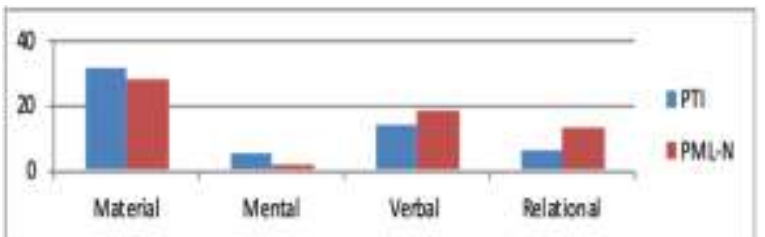

As per the results it has been found that in 'Dawn' newspaper, 'PTI' is the most active 'doer' in 'activation' and 'passivation' role by obtaining (100\%) performance in both categories by 77 occurrences in 'activation' role and 3 occurrences in 'passivation' role. Dawn has portrayed Imran Khan with 40 occurrences in the 'Verbiage' role $(50 \%)$ the most by portraying his current position. On the second number he is portrayed with 'Actor' role with 20 occurrences $(25 \%)$.

'The News' represented 'PTI' with $42 \%$ by 31 occurrences in 'activation' role whereas PML-N is portrayed with $58 \%$ in 'activation role' by 42 occurrences and $31 \%$ in 'passivation role with 19 occurrences. 'PML-N' is represented in a comparison with 'PTI' government's performance. 'PTI' promises and performance are assessed with the previous government as in existing economic crunch in country. It can be seen from news reports that PML-N performance has been portrayed a little higher positively in comparison to 'The Dawn'. In the participant role, 'The News' represented 'PML-N' with $31 \%$ by 19 occurrences in 'Actor' role whereas 'PTI' with $26 \%$ by 15 occurrences. On second position in 'Sayer' role 'PML-N' has clinched $25 \%$ with 15 occurrences the most whereas; 'PTI' is given $23 \%$ with 13 occurrences' share. In the speeches, PTI is represented in 'Affected' role with $23 \%$ with 13 occurrences whereas PML-N has all positive portrayal of them as spokespersons are associated with saying in 'Affected' role with $5 \%$ by 3 occurrences only.

The top social actors' role in 'Transitivity Process' is 'Material'. In which 'PTI' has achieved 55\% with 31 occurrences the most, while in contrast 'PML-N' has $46 \%$ with 28 occurrences. 'The News' has quoted the comparison of the performance of PML-N as a previous government with the current government in 'Verbal' role on the second position by giving PML-N 30\% of the share with 18 occurrences and $25 \%$ with 14 occurrences to 'PTI'. The findings in percentages are supporting the research objectives ' 1,2 \& 3' in representation of 'PTI' performance of 100 days, where 'Dawn' represented 'PTI' the most as 'doer' and represented as a current happening in form of hard news, while in contrast 'Dawn' has taken a rule of government in comparison with PML-N and heavily supported its write up with experts' suggestions, views, and opinions.

In 'The News' Dr.Farrukh Saleem as spokesperson of PTI has been quoted in news report for admitting the failure of economic chaos in the country, which has affected the investors and stock markets players of Pakistan [25]. In comparison, newspaper analyzes the situation with PML-N performance by mentioning the rise of National Foreign Exchange Reserves, in which dollar touched the highest peak on 30th June 2016 and Pakistan had achieved the highest growth rate (GDP) of 5.3\% in FY 2017 and in 2018 FY by $5.8 \%$ [25].

Both newspapers had quoted the sources in 'Sayer' and 'Verbiage' role to support the write up. As Bell [6] stated that the direct quoting making a journalist to have a grip on story by emphasizing with imparting information and wordings of source.

The findings are similar to 
results of research 'Print media on coverage of political parties in Pakistan: Treatment of opinion pages of 'Dawn' and 'News' that 'Dawn' is found in neutral tone as independent newspaper, while 'The News' approach is subjective [18].

The readers had given a comparison with the positive image presentation of PML-N in government and gave a road map to PTI for achieving the best for the country and improving the performance to boost up the economy by taking and planning the suitable steps. By analyzing the result 'Dawn' had given more coverage to 'PTI' in hard news, which had represented as the current political story of the day, where PML-N is nowhere to be seen. 'The News' had given a narrow difference in coverage as mostly PTI coverage is analyzed with PML-N tenure's performances with a little more weight given to PML-N.

For further future studies, the research can be conducted on any political parties' performances in their cultural context by adopting the same methodological approach with the combination of independent and mainstream newspapers. It helps to determine the political strength of a country on the press in form of power relation as per Foucault notion of power. That is supported by Wodak and Meyer [36] by stating that CDA as a most beneficial analytical technique in the maintenance of establishing and reproduction of relation of power in discourse. By adopting CDA and SFL in the existing study, the relation of power has been found out in form of results of social actors in different roles in their context.

In the study of 'The Linguistic Representation of Iranian and Western Actors of Iran's Nuclear Program in International Media: A CDA Study' by Kheirabadi \& Moghaddam [21] portrayed by CDA and SFL combination that Iranians are irrational hardliners while western actors are represented always as peace seekers and logical. That impression has been created and perceived worldwide generally by their extensive representation. In another research on 'Media discourse and the Yugoslav conflicts: Representations of self and other' by Agarin [1] found by CDA and SFL study that media portrayal of stereotyping of ethnicity led to ethnic rallies as a result. The people get motivated and start perceiving the message as a call to action.

By applying the same framework, the study of Sriwimon and Zilli [31] investigated political media discourse in gender stereotypes and the result showed that female representation was overshadowed by male politicians. Generally, it is seen that men are shown in a powerful role as compared to women. This representation leads to perceive the higher or prominent role of men in society. The society takes and functions as per the portrayal image. In another article which also supporting the study is 'When Media of a Small Nation Argue for War' by Hjarvard and Kristensen [17]. The analysis confirmed that the elite voice of people and other voices of organizations competed with newspapers as an influential medium. As per the research on 'Print media on coverage of political parties in Pakistan: Treatment of opinion pages of 'Dawn' and 'The News' it is found from analysis from CDA and SFL that 'Dawn' remained neutral in tone and language while the approach of 'The News' is subjective [18]. The current study also has found 'Dawn' reported the event with the neutral and liberal voice; while 'The News' had shown moderate political alignment in current political situation by giving suggestions

and experts' opinions. It seems that it has played a safe role in the current political scenario by looking at past relation of it with PTI political party, where PTI always against its positive coverage towards PML-N and negative coverage of PTI's stances.

\section{VII.CONCLUSION}

It has been concluded that 'Dawn' as an independent newspaper has represented the news in 'hard news' by quoting the actual happenings and sayings. In comparison 'The News' has come up with previous government's (PML-N) performance with a more positive representation of their achievements as compared to 100 days of PTI performance. 'The News' has quoted extensively the experts and PML-N spokespersons to have their say on handling the ongoing economic crunch in the country. The current economic situation is represented low as a fact as compared to previous years and enforcement can be seen for further improvement in representing the news in comparison. The political alignment of 'The News' towards 100 days of PTI is seen moderate with the findings.

\section{REFERENCES}

1. Agarin, T. (2010). Media discourse and the Yugoslav conflicts: representations of self and other. European Security, 18(4) 501-503. https://doi.org/10.1080/09662839.2010.502530

2. Ahmed, Z. S. (2012). The Role of the Pakistani Mass Media in the Lawyers' Resistance against the Musharraf Dictatorship , 2007By Zahid Shahab Ahmed. Pakistaniaat, 4(3), 61-77.

3. Almeida, C. (2018, May). For Nawaz, it' s not over till it' s over. The Dawn. Retrieved from https://www.dawn.com/news/1407192

4. BBC News. (2018, December 24). Nawaz Sharif , Pakistan ex-PM , sent back to jail for corruption. BBC News. Retrieved from https://www.bbc.com/news/world-asia-46670801

5. Bednarek, M., \& Caple, H. (2012). "Value added": Language, image and news values. Discourse, Context and Media, 1(2-3), 103-113. https://doi.org/10.1016/j.dcm.2012.05.006

6. Bell, A. (1991). The Language of News Media (First, Vol. 15) Basil Blackwell Ltd. https://doi.org/10.2307/416501

7. Chyi, H. I. (2009). Willingness to Pay for Online News: An Empirical Study on the Viability of the Subscription Model. Journal of Media Economics, 18(2), 131-142. https://doi.org/10.1207/s15327736me1802_4

8. Daldal, A. (2014). Power and Ideology in Michel Foucault and Antonio Gramsci: A Comparative. American Research Institute for Policy Development, 2(2), 149-167. Retrieved from http://rhpsnet.com/journals/rhps/Vol_2_No_2_June_2014/8.pdf

9. Dimitrova, D. V., \& Neznanski, M. (2006). Online journalism and the war in cyberspace: A comparison between U.S. and international newspapers. Journal of Computer-Mediated Communication, 12(1), 248-263. https://doi.org/10.1111/j.1083-6101.2006.00324.x

Eggins, S. (2004). An Introduction to Halliday's Systemic Functional Linguistics. Journal for the Study of English Linguistics (Second). Continuum International Publishing group, London. Retrieved from file://C:/Users/dell/Downloads/Suzanne Eggins - An Introduction to Systemic Functional Linguistics (2005, Continuum).pdf-downloaded library genesis

\section{Fairclough, N. (1995). Critical Discourse Analysis: The Critical Study of Language. Longman Group Limited}


(First). London: Longman Group Limited. https://doi.org/10.2307/329335

11. Graber, D. A., \& Smith, J. M. (2005). Political communication faces the 21st century. Journal of Communication, 55(3), 479-507. https://doi.org/10.1093/joc/55.3.479

12. Habermas, J. (2006). Political communication in media society: Does democracy still enjoy an epistemic dimension? The impact of normative theory on empirical research. Communication Theory, 16(4),

$411-426$. https://doi.org/10.1111/j.1468-2885.2006.00280.x

13. Halliday, M. A. K. (1999). Text \& Context in Functional Linguistics-The Notion of " Context" in Language Education. (M. Ghadessy, Ed.) (First). John Benjamins Publishing Company, Amsterdam \& The Netherlands.

14. Hasan, R. (2005). Pedagogy and Shaping Conscious (E) : Linguistic and Social Processes- Ch\#1-Society, language and the mind: the meta-dialogism of Basil Bernstein's theory. (F. Christie, Ed.) (Second). Great Britain: Bloomsbury Publishing PLC

15. Heer, J. D., Vergotte, J., Vuyst, S. De, \& Leuven, S. Van. (2019). The bits and bytes of gender bias in online news : a quantitative content analysis of the representation of women in Vice . com. Feminist Media Studies, 00(00), 1-17. https://doi.org/10.1080/14680777.2019.1574858

16. Hjarvard, S., \& Kristensen, N. N. (2014). When media of a small nation argue for war. Media, War and Conflict, 7(1), 51-69. https://doi.org/10.1177/1750635213516560

17. Jan, Mirza, Raza, Muhammad Riaz, Siddiq, M. \& S. N. (2013). Print Media on Coverage of Political Parties in Pakistan Treatment of Opinion Pages of the "Dawn" and "News." Gomal University Journal of Research, 29(1). Retrieved from http://www.gu.edu.pk/New/GUJR/PDF/June-2013

18. Jóhannsdóttir, V. (2018). Commercialization in the Icelandic Press : An analysis of hard and soft news in major print and online media in Iceland in times of change. Journalism, 1(17). https://doi.org/10.1177/1464884918768494

19. Joseph, J. E. (2006). Language and Politics. (K. Davies, Alan \& Mitchell, Ed.), The Handbook of Applied Linguistics. Edinburgh University Press, Great Britain https://doi.org/10.1002/9780470757000.ch14

20. Kheirabadi, R., \& Moghaddam, S. B. A. (2012). The Linguistic Representation of Iranian and Western Actors of Iran's Nuclear Program in International Media: A CDA Study. Theory and Practice in Language Studies, 2(10), 2183-2188. https://doi.org/10.4304/tpls.2.10.2183-2188

21. Ksiazek, Thomas B, Peer, L. \&, \& Lessard, K. (2016). User engagement with online news : Conceptualizing interactivity and exploring the relationship between online news videos and user comments. New Media \& Society, 18(3). https://doi.org/10.1177/1461444814545073

22. Malik, S., \& Iqbal, Z. (2011). Construction of Taliban image in Pakistan: Discourse analysis of editorials of Dawn and The News. China Media Research Journal, 7(2), 46-56.

23. Matthiessen, C. M. I. M. \& H. (2014). Halliday 's Introduction to Functional Grammar (Fourth). Great Britain: Routledge. https://doi.org/10.4324/9780203431269

24. Mustafa, K. (2018, November). Policy decisions : PTI govt lags behind PML-N in first 100-day comparison. The News. Retrieved from https://www.thenews.com.pk/print/399480-policy-decisions-ptigovt-lags-behind-pml-n-in-first-100-day-comparison

25. Noor, S. N. F. M. (2017). The Representation of Social Actors in the Graduate Employability Issue: Online News and the Government Document. International Journal of Society, Culture \& Language, 5(1), 82-93. https://doi.org/http://dx.doi.org/10.1038/s41598-017-02314-x

26. Orpin, D. (2005). Corpus Linguistics and Critical Discourse Analysis: Examining the ideology of sleaze. International Journal of Corpus Linguistics, 10(1), 37-61. https://doi.org/10.1075/ijcl.10.1.03orp

27. Page, B. (1996). The Mass Media as Political Actors. Political Science \& Politics, 29(1), 20-24. https://doi.org/137.111.13.162

28. Pakistan, G. of. (1973). The Constitution of the Islamic Republic of Pakistan (As Modified upto February 28, 2012). https://doi.org/March 11, 2015

29. PTI. (2018). Naya Pakistan-PTI Manifesto.

30. Sriwimon, L., \& Zilli, P. J. (2017). Applying Critical Discourse Analysis as a conceptual framework for investigating gender stereotypes in political media discourse. Kasetsart Journal of Social Sciences, 38(2), 136-142 https://doi.org/10.1016/j.kjss.2016.04.004

31. Thompson, G. (1999). Text \& Context in Functional LinguisticsActing the part Lexico-grammatical choices and contextual factors. (M. Ghadessy, Ed.) (First). s Publishing Company, Amsterdam \& The Netherlands. Retrieved from http://ebookcentral.proquest.com/lib/uthm-ebooks/detail.action? docID $=623206$. Created

32. Thomson, E. A., White, P. R. R., \& Kitley, P. (2008). Objectivity" and "hard news" reporting across cultures: Comparing the news report in english, french, japanese and indonesian journalism. Journalism Studies, 9(2), https://doi.org/10.1080/14616700701848261

33. van Leeuwen, T. (2005). Introducing Social Semiotics. Introducing Social Semiotics (First). USA \& Canada: Routledge. Retrieved from http://orca.cf.ac.uk/3739/

34. Wodak, R. (2006). Mediation between discourse and society: Assessing cognitive approaches in CDA. Discourse Studies, 8(1), 179-190. https://doi.org/10.1177/1461445606059566

35. Wodak, R., \& Meyer, M. (2009). Critical Discourse Analysis: History, Agenda, Theory, and Methodology 1. Methods for Critical Discourse Analysis, (November), 1-33. Retrieved from https://www.researchgate.net/publication/265678850\%0ACritic al

\section{AUTHORS' PROFILE}

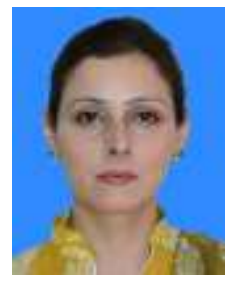

Saira Asad is a current Ph.D scholar at Universiti Tun Hussein Onn Malaysia (UTHM), Johar, Malaysia. She is holding MSc. Communication Sciences, M.A International Relations and M.A Political Science from Pakistan. Her field of interest is in Mediated Discourse Analysis, Media, Media Discourse, Political Communication, Elections, Genre Study, Critical Discourse Analysis (CDA), Semiotic Analysis,, Appraisal Analysis (Conversation Analysis) and Transitivity Analysis. She belongs from Pakistan and currently pursuing her degree and living at Johar Bahru, Malaysia and can be contacted on saira.asad2011@gmail.com

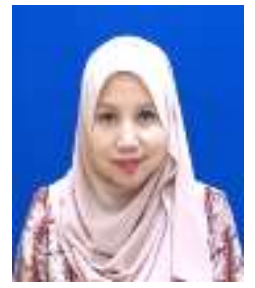

Dr.Siti Noor Fazelah Binti Mohd Noor is a ful time faculty as Senior Lecturer at Universiti Tun Hussein Onn Malaysia. Her field of specialization is Discourse Studies (Including Critical Linguistics, Text Linguistics, Mediated Discourse Analysis, CDA, Genre Studies, Genre Analysis, Conversation Analysis, Social Interactions Analysis (Macro and Micro), Semiotics). She is supervising number of international students of masters as well as $\mathrm{Ph} . \mathrm{D}$. She holds her degree from Macquarie University, Sydney, Australia with number of publications to her credit. She has supervised the current research and can be contacted on fazelah@uthm.edu.my

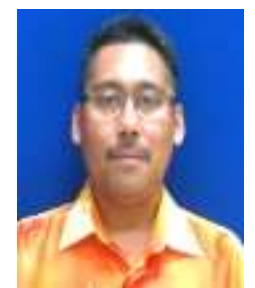

Dr.Lutfan Bin Jaes is a full time faculty as Senior Lecturer at Universiti Tun Hussein Onn Malaysia. He has acquired his Ph.D from Universiti Utara Malaysia. His field of interest is leadership. He has authored number of publications in journals and credits various chapters of books to his name. $\mathrm{He}$ has co-supervised the current research and can be contacted on lutfan@uthm.edu.my 